\title{
Training of judiciaries and the effectiveness of the judicial system in Russia
}

\author{
Tatyana Anatolyevna Dolgopolova ${ }^{1 *}$, Viktor Aleksandrovich Maiboroda ${ }^{2}$, Elvira Tagirovna \\ Maiboroda $^{2}$, Yuri Alekseevich Potapov ${ }^{1}$, and Yulia Nikolaevna Tarasova ${ }^{1}$ \\ ${ }^{1}$ North-West Branch of the Russian State University of Justice, Department of General Theoretical \\ Legal Disciplines, Saint Petersburg, Russia \\ ${ }^{2}$ North-West Institute (branch) of the Russian Academy of National Economy and Public \\ Administration under the President of the Russian Federation, Department of Law, Saint Petersburg, \\ Russia
}

\begin{abstract}
The article examines the theoretical, legal, social and psychological aspects of the formation of a highly effective judiciary in Russia on the basis of a systematic approach in the preparation and selection of personnel for the judicial system. The authors substantiate the most significant tasks of forming the professional identity of Russian judges based on social and psychological research, practical experience of legal personnel, information educational technologies, and analyze the results of assessing the effectiveness of the Russian judicial system according to European standards. When writing the article, general scientific and special research methods were used: structural and functional analysis, comparative legal and analytical methods. The research carried out by the authors made it possible to obtain the following results: to form a comprehensive idea of the identity of a judge based on the concepts of self-esteem, behavior control, communication characteristics and social abilities. It is possible to use these results in the academic process of educational institutions of secondary vocational education and higher education, in the selection of personnel and social and psychological support for the activities of judges and employees of the judicial apparatus. The importance of such studies is associated with the high social significance of this type of activity, its impact on the level of social trust in law and legality.
\end{abstract}

Keywords: judiciary, personnel, career, ideal judge

\section{Introduction}

The modern justice system in the Russian Federation is one of the fundamental institutions of the organization of society. From a formal legal point of view, it is an independent part of the system of power, constituting, according to the Constitution of the Russian Federation, a single whole and divided into executive, legislative and judicial powers [1]. From the factual point of view, the perception of courts as bodies endowed with power competence, autonomous from any other public competence, is presumed in the public consciousness.

\footnotetext{
* Corresponding author: dolgopolova_ta@inbox.ru
} 
Like other state institutions and organizations of society, the system of training personnel for the judiciary was formed with the incorporation of the socialist state experience, the administration of justice in which was carried out by the people's court, which in turn was in obvious dependence on the Party and the Soviet governing bodies. However, the transformation of the judicial system from the Soviet to the democratic one, which proclaims the primacy of law as the main dogma, did not take place in a revolutionary way. It was carried out in an exclusively evolutionary way. It is this feature that distinguishes the Russian justice system from other institutions of power. For comparison, it is enough to give an example of the reorganization of property relations implemented through a shock, revolutionary privatization [2].

Accordingly, the process of the formation and development of the Russian justice system and its qualitative characteristics also underwent rethinking. Increasing the efficiency of training qualified personnel for the judicial system in professional and intellectual terms will allow solving one of the most important functions of power in modern Russia.

The judicial system (including the judiciaries), being by its nature a conservative institution, has carried out its own transformation by evolutionary means. At the same time, a number of criteria set by the law to candidates for judges and to persons administering justice have remained essentially unchanged for almost thirty years, which makes it possible to formulate an assertion about an intergenerational system-forming factor in the formation and improvement of the judicial system.

The issues of increasing the efficiency of justice in different years were developed in the works [3-4], et al.

The studies [1-5] are devoted to the problems of training personnel for the judicial system of Russia. The features of training the judiciaries within the systems of continental and Anglo-Saxon law are described in the work [6], et al.

Such aspects of the judicial system functioning as its perception in the public mind and the tasks of strengthening confidence in the judiciary were studied both by domestic [7-8], and foreign [9] experts.

The objectives of this study are to identify the most significant aspects of professional, psychological and social training of judiciaries for a more effective functioning of the judicial power; to study the experience of other countries and increase the social significance of the judicial procedure; to create a qualitative assessment of the judiciary's social role in solving the problems of creating the democratic foundations of the rule of law; to form the professional and personal identity of the future judge in the modern educational process.

Among the tasks formulated, the following should be noted:

1) to consider the continuity of the judiciary formation principles in the Russian Federation;

2) to analyze the psychological and pedagogical attitudes and stages of career development from the standpoint of readiness to carry out activities as judges;

3) to reveal the features of the professional identity of judges on the example of psychological research;

4) to assess the effectiveness of judicial activity using the criteria of the European Commission for the effectiveness of justice of the Council of Europe.

\section{Methods}

The research methods included a structural and functional analysis and an analytical method, which made it possible to identify the theoretical and methodological foundations of the concept of "efficiency of the judicial system". 
Involvement of the comparative approach methodology increased the effectiveness of the study in analyzing the Russian and foreign experience in increasing the authority of judiciaries and forming a favorable public opinion about the judicial system [6,9].

\section{$3 \quad$ Results}

Modern reality dictates its own standards of the professional prestige, type of activity, attempts to combine prestige and economic benefits. Unfortunately, there are no modern equivalents for the introduction to the professional environment through initiation. It should be preserved in the form of a tradition of training lawyers to obtain the right to enter the guild, to learn from the master, to step-by-step mastering the secrets of professional skills: familiarizing with the master's value system, repeating patterns of behavior (identification principle) [10].

Thus, one of the key issues of the professional identity of judges in Russia, in other countries, is the question of the relationship between a judge's self-esteem and his/her perception of its personality assessment by the social environment. Other characteristics of the personality typology of a judge are such features as the ratio of extraversion-introversion (openness-closeness) in social contacts. Following the legislation and corporate documents, the judge is encouraged to communication that cannot harm the performance of his/her professional duties, diminish the role of the judiciary in society.

In addition to these factors, the activity of a judge is characterized by independence and self-reliance. In this case, the factor of behavior control, the ability to manage working time, to structure the goals and objectives of the activity become of great importance.

This study with the participation of 57 federal judges (judges of district courts of general jurisdiction) and 75 employees of the court staff (assistant judges) reflects an attempt to investigate and describe the image of the "Ideal Judge".

Using mathematical processing and qualitative analysis, the following results were obtained:

1. The image of a judge reflects in general a good understanding of the psychological portrait of a judge, both by the judges themselves and by those who work in the judicial system, but are not judges.

2. The peculiarity of perception by judges differs according to the scales - "Scale of Control", "Scale of Openness" and "Scale of Social Abilities".

On the Scale of Control, the judges consider themselves more pedantic, being in control of the situation, constant in habits.

On the Scale of Openness, judges see themselves as more withdrawn, detached, hiding true emotional manifestations. Presumably, the influence of the principle of impartiality causes the formation of the professional and personal identity of judges.

On a Scale of Social Ability, judges describe themselves as less sociable, less competitive.

Brief conclusion: the professional activity of a judge is individual, does not imply direct competition, the results of work are also influenced by a large social load and "fatigue with people".

The data obtained using this methodology allow individual and group work on issues of professional motivation, identity and the choice of response strategies in situations of stress.

It is important to carry out similar techniques at the stage of training lawyers, to study the features of the value system formation, behavioral reactions, and communication skills. The importance of such studies is associated with the high social significance of this type of activity, its impact on the level of social trust in law and legality. 


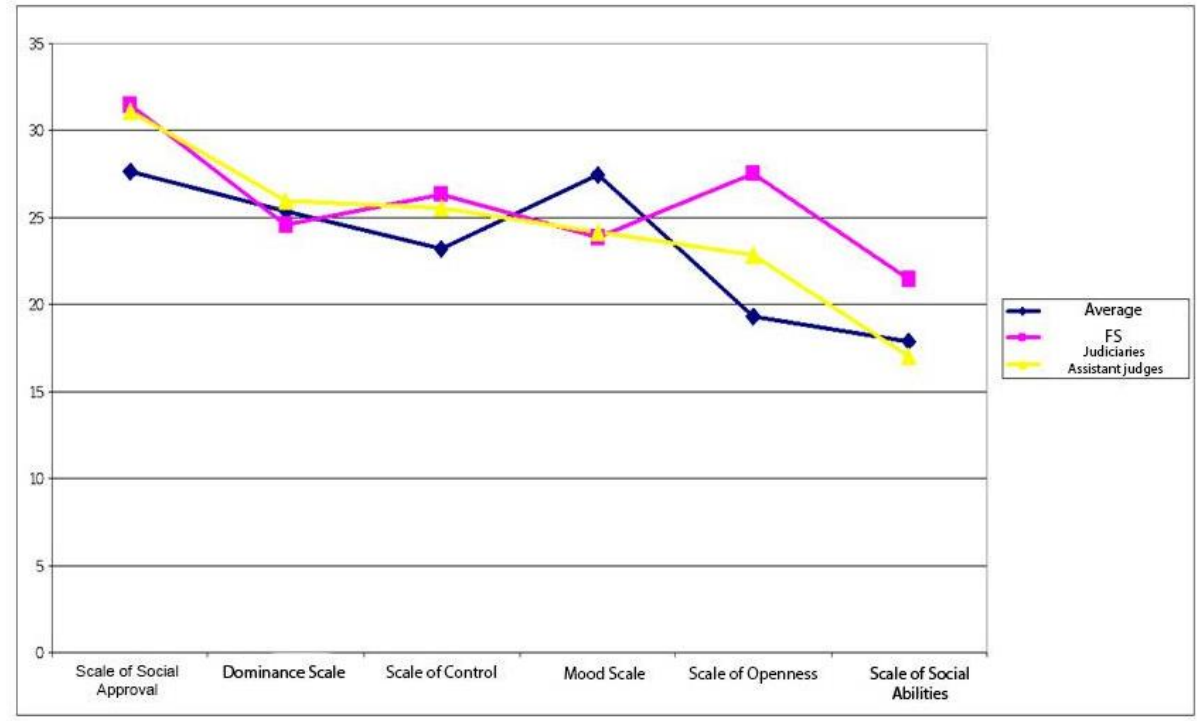

Fig.1. The image of the ideal judge.

\section{Discussion}

According to a number of domestic researchers [5, 11], career growth has its own stages limited by age and determining subsequent fluctuations in the professional career of a judge, which have both legal and psychological limitations.

The activity of a judge, like the entire modern life, dictates the combination of sometimes incompatible criteria: on the one hand, being public figures, representatives of the judiciary, lawyers must be able to maintain the interest of society and the media in their activities under the existing restrictions on publicity in official and non-official activities. Such requirements dictate a special attitude towards working with information, the strict use of the principle of confidentiality in work, and a limitation of the circle of contacts.

According to experts in labor psychology, inclusion in the professional community, awareness of the level of responsibility for their work and the acquisition of professional skills occur not only mechanically, but also through familiarization with traditions, through the study of the activity style of prominent representatives of this social sphere [12, 13].

The comprehension of professional skills by judges is carried out gradually. When selecting for a position, attention is paid to the potential of the candidate: the peculiarities of his/her mental activity, emotional and volitional stability, working capacity, personal maturity.

Noting certain tendencies in work with personnel, foreign and domestic researchers point out that, at present, such a phenomenon as a decrease in the degree of employee loyalty to their organization is becoming widespread. In the course of management activities, significant changes take place in the quantitative and qualitative composition of the personnel. These circumstances, in turn, affect the redistribution of functional responsibilities of employees and imply a change in the organizational policy of the institution, as well as the content and form of organizational communications $[14,8]$.

According to the European Commission for the Efficiency of Justice of the Council of Europe (CEPEJ), the indicators of the judiciary effectiveness are the terms of consideration of civil cases and economic disputes, the absence of red tape in the consideration of cases, 
the use of modern information technologies by the courts, the efficiency of the judicial system existence, the progressiveness and professionalism of judiciaries [3, 15].

A number of Russian researchers, relying on the data of annual surveys and their own observations, conclude that only a small part of the respondents (23-29\%) fully trust the court, while $57-65 \%$ do not trust the court to one degree or another. However, there are also positive trends - over the past seven years, the index of mistrust has decreased from 21 in 2012 to 13.5 in 2018 [4, 7].

\section{Conclusion}

Noting the undoubted high importance of judicial activity in the modern state and the social role of a judge as a bearer of legal dogma, one should strive to revive in personnel training the high moral qualities of responsibility for the fate of each person and patronymic in general, no matter how acute it sounds. Many examples of serving in the judicial field in prerevolutionary Russia are striking evidence of this, which created the glory of domestic jurisprudence. A high level of moral qualities, along with professional training, will allow, in the authors' opinion, the achievement of a more efficient and high-quality level of legal proceedings, an attainable level of legality, law order and legal culture.

\section{References}

1. M.I. Kleandrov, B. Russ. Acad. Sci., 82(5), 395-401 (2012)

2. V.A. Mayboroda, Int. J. of Eng. and Technol. (UAE) 7(4), 351-354 (2018). https://doi.org/10.14419/ijet.v7i4.38.24499

3. R.A. Gurbanov, State and Law, 10, 112-115 (2015)

4. A.Yu. Salomatin, A.F. Meshcheryakova, News of Higher Educ. Inst. Volga Region. Social Sciences 4(40), 39-48 (2016). https://doi.org/10.21685/2072-3016-2016-4-4

5. D.K. Nechevin, L.M. Kolodkin, Acad. Thought 1(2), 7-10 (2018)

6. F. Selita, V. Smereczynska, R. Chapman, T. Toivainen, Y. Kovas, Eur. J. of Hum. Genet. Natue Publishing Group 28(10), 1322-1330 (2020). https://doi.org/10.1038/s41431-020-0650-8

7. Yu.A. Nisnevich, Sociol. Res. 45(8), 84-95 (2019). https://doi.org/10.31857/S013216250006165-4

8. O.V. Romanovskaya, Judge 1, 24-28 (2015)

9. R. Bill Chavez, J. Lat. Am. Stud. 36(3), 451-478 (2004). https://doi.org/10.1017/S0022216X04007758

10. V.V. Orobinsky, Chemu ne uchat na yurfake [What is not taught at the law faculty], 4th ed. (Feniks, Rostov-On-Don, 2018)

11. A.Ya. Kibanov, T.V. Lukyanova, A.S. Lobacheva, Innovacii na gosudarstvennoy grazhdanskoy sluzhbe: Planirovanie karernogo rosta [Innovations in the civil service: Career planning] (Cooper Book, Moscow, 2015)

12. M.O. Korobko, Upravlenie personalom [Personnel management] (MEI Publishing House, Moscow, 2020)

13. N.S. Pryazhnikov, E.Yu. Pryazhnikova, Psikhologiya truda I chelovecheskogo dostoinstva [Psychology of work and human dignity] (Academy, Moscow, 2003)

14. D.P. Gavra, D.P. Shishkin, B. of St. Petersburg University. Series 9. Philology. Oriental Studies. Journalism, 4, 128-136 (2012) 
15. V. Yermolov, The judicial system of Russia is recognized as the most efficient and economical in Europe (2020). Accessed on: November 24, 2020. [Online]. Available: http://rapsinews.ru/judicial_analyst/20201103/306468156.html 